Gut, 1973, 14, 478-484

\title{
Periodic hypokalaemic paralysis, adrenal adenoma, and normal colonic transport of sodium and potassium
}

\author{
PETER RICHARDS ${ }^{1}$, M. B. S. JONES, AND W. S. PEART \\ From the Medical Unit, St Mary's Hospital Medical School, London
}

SUMMARY A 47-year-old woman was cured of hypokalaemia and recurrent paralysis by the excision of an adrenal adenoma. Hypertension was initially ameliorated but was not cured. Suppression of plasma renin activity was abolished when the adenoma was excised. Repeated measurement of plasma corticosteroids before operation showed a slight increase in aldosterone and normal plasma concentrations of deoxycorticosterone, corticosterone, and cortisol. No evidence of excess mineralocorticoid was obtained from measurement of the electrolyte composition of colonic fluid or of rectal potential difference, although both these variables responded normally to salt depletion and exogenous aldosterone. The diagnostic importance of the paradoxically normal colonic measurements is emphasized and the possibility is considered that the adenoma may have secreted an unidentified hormone.

The colon normally responds to excessive plasma concentrations of aldosterone, corticosterone, and deoxycorticosterone by modifying faecal fluid so that the concentration of sodium is very low and that of potassium high (Wrong, Morrison, and Hurst, 1961 ; Wrong and Metcalfe-Gibson, 1965; Richards, 1969). Administration of fludrocortisone and a large dose of cortisol (Richards, 1969; Charron, Leme, Wilson, Ing, and Wrong, 1969) have a similar effect. Aldosterone and fludrocortisone also increase the electrical potential difference (pd) across the colonic mucosa, probably as a direct result of stimulation of active sodium transport (Edmonds and Godfrey, 1970). The effects of adrenal corticosteroid excess upon ion transport in the colon can readily be monitored from the concentration of sodium and potassium in faecal fluid (Wrong, Morrison, and Hurst, 1961; Wrong and Metcalfe-Gibson, 1965; Richards, 1969) and by measurement of rectal transmucosal pd (Edmonds and Godfrey, 1970; Edmonds and Richards, 1970). The colonic response to adrenal corticosteroid excess is a useful aid to diagnosis because, unlike the kidney (August, Nelson, and Thorn, 1958), the colon apparently does

'Present address: Department of Medicine, St George's Hospital, Hyde Park Corner, London S.W 1

Received for publication 2 March 1973. not escape from the action of these hormones. One patient has been described in whom colonic sodium fluxes were apparently normal and were unchanged by the excision of an aldosterone-secreting adrenal adenoma; potassium influx was nevertheless increased and returned to normal after operation (Shields, Miles, and Gilbertson, 1968). The discrepancy between sodium and potassium transport in that case remains unexplained.

We are unaware of any reports of patients with proved or apparent mineralocorticoid excess in whom both colonic sodium and potassium transport were normal. The patient whom we describe here and who was reported briefly elsewhere (Richards, 1971) presented with hypertension and periodic hypokalaemic paralysis. Hypertension was ameliorated and hypokalaemia cured by the excision of an adrenal adenoma. Plasma concentrations of aldosterone were little above normal, and concentrations of corticosterone, deoxycorticosterone, and cortisol were repeatedly normal. Whatever the identity of the adrenal hormone responsible for hypokalaemia it seemed that the colonic mucosa had either become refractory to its action or that it had never been influenced by it. Our investigations favour but do not prove the latter explanation; they also raise the alternative possibility that the adrenal hormone secreted in excess may have been an unidentified 
adrenal cortical hormone. The fact that this patient's functioning adrenal adenoma could not be detected either from the electrolyte composition of colonic fluid or from measurement of rectal pd is important diagnostically and, more than that, it raises fundamental questions which merit a search for similar cases.

\section{Case History}

A 47-year-old woman was hypertensive during pregnancies in 1955 and 1960 but was not followed up. In 1966 she experienced headaches and nocturia. In 1967 she was investigated for hypertension in another hospital; no cause was found and she was treated with debrisoquine without a diuretic. Her blood pressure was difficult to control and ranged from $250 / 130$ to $180 / 110 \mathrm{~mm} \mathrm{Hg}$. The plasma potassium concentration was estimated several times and was never less than 3.2 m-equiv per litre. Both her parents had died when she was young, her father with pleurisy and her mother suddenly in her early forties. Her only relations were two cousins who were well.

In March 1969 during a visit to London her legs became weak and her muscles were painful but not tender. Later that evening she became unable to lift her arms or to walk; she could raise herself only with difficulty. Blood taken the next day and sent to a regional laboratory without prior separation of plasma from red cells had a plasma potassium of $3 \cdot 0$ m-equiv per litre. Two days later after she had been given an oral potassium supplement and her strength was returning the plasma potassium was still only 3.0 m-equiv per litre. In June 1969 she abruptly developed tetany, and the following day she again became weak although weakness was less severe than in the first attack. She did not call her doctor and the episode passed off spontaneously in the course of one week.

In October 1969 one tablet containing cyclopenthiazide $0.25 \mathrm{mg}$ and potassium chloride 600 mg were added daily to her treatment. This was the first time she had received a diuretic. Within two weeks she became grossly weak in limbs and trunk. On arrival at hospital her plasma sodium was 145 m-equiv per litre, potassium 1.2 m-equiv per litre, and total carbon dioxide $\left(\mathrm{TCO}_{2}\right) 34 \mathrm{mmol}$ per litre. In the first 24 hours in hospital she passed only 7 m-equiv of potassium in 1.5 litres of urine. After an intravenous infusion of potassium had increased her plasma potassium to $3.0 \mathrm{~m}$-equiv per litre she was transferred to London. On arrival at St Mary's Hospital her arms and legs were weak but the tendon reflexes were brisk. Trousseau's sign was present but Chvostek's sign was absent. Blood pressure was
$260 / 160$ recumbent, left ventricular hypertrophy was evident clinically, the optic fundi showed only arteriovenous nipping, and the urine contained a trace of protein. She denied taking either purgatives or liquorice, and because of her persistently small stool volumes during three hospital admissions, her stable personality and her later response to adrenalectomy, we accept her denial without question. Her serum calcium was $9.1 \mathrm{mg}$ per $100 \mathrm{ml}$. An ${ }^{131}$ I uptake was normal. Further biochemical investigations are described below. Adrenal phlebograms were technically unsuccessful; perirenal air insufflation outlined a normal left adrenal but the right adrenal appeared slightly expanded.

Before each of the three episodes of hypokalaemic paralysis she missed one or two menstrual periods. She missed another in April 1970 and on 5 May her plasma potassium was $1.6 \mathrm{~m}$-equiv per litre. Because of the remote possibility of an ovarian tumour both ovaries were examined by laparoscopy by $\mathrm{Mr}$ G. Pinker before adrenal exploration. No abnormalities were seen. In July 1970 the right adrenal, which contained an adenoma $1.5 \mathrm{~cm}$ in diameter, was excised by $\mathrm{Mr} \mathrm{K}$. Owen. Her plasma potassium concentration has remained normal in the two years since operation. Although for a few months after adrenalectomy she required less treatment than before to control her blood pressure, she now requires doses of methyldopa and bethanidine similar to her preoperative treatment.

\section{Methods}

All plasma corticosteroid assays and recumbent renin estimations were taken after at least one hour recumbent. Plasma aldosterone and corticosterone concentrations were measured by double isotope dilution assay by the method of Fraser and James (1968). Plasma deoxycorticosterone was measured by the radioimmunoassay method of Arnold and James (1971). Plasma renin activity was measured by radioimmunoassay (Boyd, Adamson, Fitz, and Peart, 1969). Total exchangeable sodium $(\mathrm{Na})$ and total exchangeable potassium were measured by radioisotope dilution using ${ }^{24} \mathrm{Na}$ and ${ }^{42} \mathrm{~K}$ (Brown, Davies, Lever, Peart, and Robertson, 1965). Concentrations of sodium and potassium in plasma and urine were measured by flame photometry.

A dialysate of faeces was obtained in vivo by the technique of Wrong (Wrong, Morrison, and Hurst, 1961) and the concentrations of sodium and potassium in the dialysate were measured by flame photometry. The normal mean and $95 \%$ range is sodium 18.5 m-equiv per litre $(3 \cdot 6-94)$, potassium 79 m-equiv per litre (21-137), sodium/potassium $(\mathrm{Na} / \mathrm{K})$ ratio $0.24(0.029-2.02)$ (Richards, 1969; 
Charron, Leme, Wilson, Ing, and Wrong, 1969). The corresponding figures for individuals with excess aldosterone were sodium $2.3 \mathrm{~m}$-equiv per litre $(0 \cdot 7-9 \cdot 2)$, potassium 139 m-equiv per litre (106-171), and Na/K 0.016 (0.005-0.049) (Richards, 1969). Rectal transmucosal pd was measured as described by Edmonds and Godfrey (1970). The normal range and SD was $26 \pm 18 \mathrm{mV}$ (Edmonds and Richards, 1970).

Sodium and potassium balance was expressed as the difference between intake and urinary excretion. We know that losses of electrolytes in faeces were small in relation to urine because her stools were hard and small and the concentration of sodium and potassium in the fluid phase of these stools was normal or below normal (fig 2).

\section{Results of Investigation}

\section{RENAL FUNCTION}

Her blood urea was $26 \mathrm{mg}$ per $100 \mathrm{ml}$ and the creatinine clearance $139 \mathrm{ml}$ per minute. She had neither glycosuria nor abnormal aminoaciduria. The minimal urine $\mathrm{pH}$ after ammonium chloride $(0.1 \mathrm{mg}$ per kg body weight) was 5.09 and the maximum urine osmolality after 5 units of pitressin tannate in oil was $553 \mathrm{mOsm}$ per $\mathbf{k g}$. When her plasma potassium concentration was less than 2 m-equiv per litre she excreted 7 m-equiv of potassium in the urine in 24 hours. On the fourth day of a diet containing 20 m-equiv of potassium when potassium-repleted she had reduced her urinary excretion of potassium to
30 m-equiv. An intravenous pyelogram and renal arteriogram were normal.

RESPONSE OF PLASMA POTASSIUM AND

TOTAL CARBON DIOXIDE TO SPIRONOLACTONE, TRIAMPTERENE, AND

AMINOGLUTETHIMIDE (FIG 1)

After the initial period of potassium repletion, intravenously and orally, the plasma potassium level fell below 3 m-equiv per litre and the $\mathrm{TCO}_{2}$ increased above $30 \mathrm{mmol}$ per litre if she received no potassium supplement or treatment other than hypotensive drugs for longer than three weeks. Spironolactone $300 \mathrm{mg}$ daily restored both variables to normal; triampterene $150 \mathrm{mg}$ daily prevented the plasma potassium concentration falling below 3 m-equiv per litre but did not raise it to the same extent as spironolactone. Amiloride was not available at this time. Aminoglutethimide was given for only three days because her operation was imminent: the plasma potassium increased from $3 \cdot 2$ to 3.8 m-equiv per litre. At no time during these periods of treatment was her blood pressure fully restored to normal, although it was possible to reduce the dose of bethanidine.

SODIUM AND POTASSIUM BALANCE STUDIES

In the first three days of treatment with spironolactone $300 \mathrm{mg}$ daily she retained $120 \mathrm{~m}$-equiv of potassium and lost $60 \mathrm{~m}$-equiv of sodium. In the first five days immediately after stopping spironolactone $300 \mathrm{mg}$ daily for 16 days she retained 370

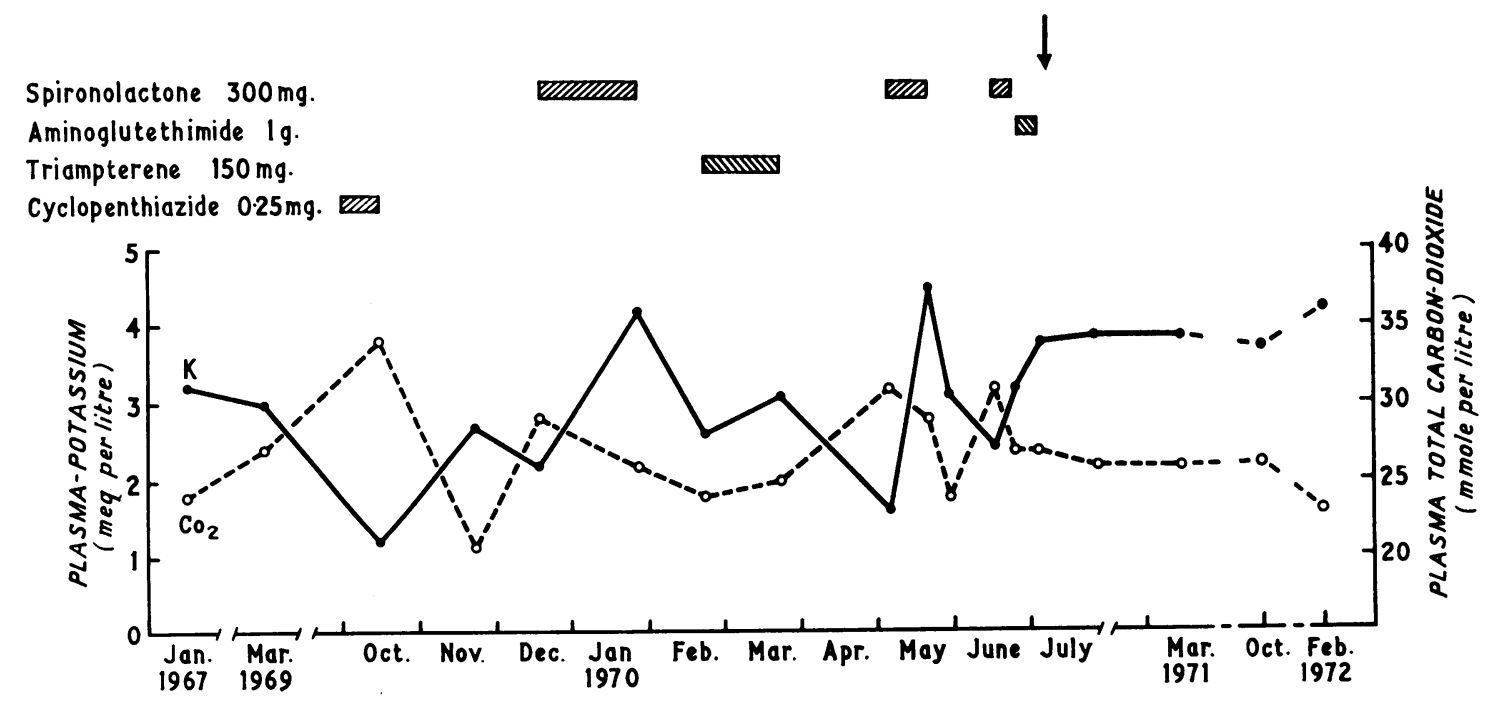

Fig 1 Plasma potassium $(\mathrm{K})$ and total carbon dioxide $\left(\mathrm{CO}_{2}\right)$ from January 1969 to February 1972. The arrow marks right adrenalectomy. 
m-equiv of sodium with a strikingly small loss of less than 50 m-equiv of potassium when taking a diet which contained 120 m-equiv of sodium and 70 m-equiv of potassium. During three days' treatment with aminoglutethimide $1 \mathrm{~g}$ daily she lost 140 m-equiv of sodium and retained 130 m-equiv of potassium.

\section{PLASMA RENIN ACTIVITY (TABLE)}

The plasma renin activity was both depressed and suppressed: renin activity was barely detectable with the patient recumbent or standing and was not elevated one hour after $20 \mathrm{mg}$ of frusemide intravenously. After five days on a diet which contained 20 m-equiv sodium the plasma renin activity (124 $\mathrm{pg}$ angiotensin $\mathrm{I} / \mathrm{ml} / \mathrm{hr}$ ) was in the low-normal range, a level also achieved on the third day of treatment with aminoglutethimide. A very high plasma renin activity $(4320 \mathrm{pg}$ angiotensin $\mathrm{I} / \mathrm{ml} / \mathrm{hr})$ was found after two weeks with spironolactone. After the excision of the adrenal adenoma the plasma renin was high (1650 $\mathrm{pg}$ angiotensin $\mathrm{I} / \mathrm{ml} / \mathrm{hr}$ on the tenth postoperative day) and six months after operation it was normal and increased normally in response to frusemide $20 \mathrm{mg}$ intravenously.

\section{PLASMA COTICOSTEROID CONCENTRATIONS (TABLE)}

The plasma aldosterone concentration $(13,12$, and $9 \mathrm{ng}$ per $100 \mathrm{ml}$ over a period of eight months) was not grossly increased but was above our recently re-defined normal range; it was, however, within the normal range of others who use the same method (see discussion). Plasma potassium concentration was greater than $3.3 \mathrm{~m}$-equiv per litre when plasma corticosteroids were measured except during the period of aldosterone administration. The concentrations of deoxycorticosterone $(7,11$, and $19 \mathrm{ng}$ per $100 \mathrm{ml})$ and corticosterone $(0.03$ and $0.05 \mu \mathrm{g}$ per $100 \mathrm{ml}$ ) were normal. On the third day of treatment with spironolactone the concentration of aldosterone had increased to $22 \mathrm{ng}$ per $100 \mathrm{ml}$ although the renin activity was hardly detectable. After treatment with spironolactone for two weeks both the aldosterone $(57 \mathrm{ng}$ per $100 \mathrm{ml})$ and deoxycorticosterone (106 $\mathrm{ng}$ per $100 \mathrm{ml}$ ) concentrations were considerably increased. Ten days after right adrenalectomy the plasma aldosterone and deoxycorticosterone concentrations were normal $(5 \mathrm{ng}$ per $100 \mathrm{ml}$ and $1 \mathrm{ng}$ per $100 \mathrm{ml}$ ) and lower than they had been at any other time during her investigation.

\section{SODIUM AND POTASSIUM CONCENTRATIONS} IN FAECAL DIALYSATE (FIG 2)

The concentrations of sodium and potassium in a dialysate of faeces in vivo were normal when she was untreated and were not significantly altered during treatment with spironolactone $300 \mathrm{mg}$ daily for three days. During six days on a low-salt diet the concentration of sodium fell below the normal range, the concentration of potassium increased, and the $\mathrm{Na} / \mathrm{K}$ ratio fell below normal. These changes were accentuated by treatment with aldosterone. After operation the sodium concentration and $\mathrm{Na} / \mathrm{K}$ ratio remained normal although the concentration of potassium increased.

RECTAL TRANSMUCOSAL PD (FIG 3)

The changes in electrolyte composition of colonic fluid dialysate were generally mirrored in the rectal pd. Before and after operation the pd was normal. The pd fell in response to treatment with spironolactone; this was the only discrepancy with the faecal electrolyte concentrations, which were unaltered by spironolactone. The pd increased to near the upper limit of normal during the six-day period of salt

\begin{tabular}{|c|c|c|c|c|c|c|c|}
\hline Conditions at Time of Study & $\begin{array}{l}\text { Plasma } \\
\text { Renin } \\
\text { Recumbent } \\
\text { (pg angio- } \\
\text { tensin I/ml/ } \\
\text { hr) (normal } \\
60-540)\end{array}$ & $\begin{array}{l}\text { Plasma } \\
\text { Renin } \\
\text { Upright }\end{array}$ & $\begin{array}{l}\text { Plasma } \\
\text { Renin } \\
\text { after } \\
\text { Frusemide }\end{array}$ & $\begin{array}{l}\text { Plasma } \\
\text { Aldosterone } \\
\text { (ng/100 ml) } \\
\text { (normal } 0-5)^{1}\end{array}$ & $\begin{array}{l}\text { Plasma } \\
\text { Deoxycorti- } \\
\text { costerone } \\
\text { (ng/100 ml) } \\
\text { (normal } \\
0-20)\end{array}$ & $\begin{array}{l}\text { Plasma } \\
\text { Cortico- } \\
\text { sterone } \\
(\mu \mathrm{g} / 100 \mathrm{ml}) \\
(\text { normal } 0 \cdot 1- \\
2 \cdot 3)\end{array}$ & $\begin{array}{l}\text { Plasma } \\
\text { Cortisol } \\
(\mu \mathrm{g} / 100 \mathrm{ml}) \\
\text { (normal 5-20) }\end{array}$ \\
\hline No treatment (7 Nov 1969) & 11 & 39 & 20 & 13 & 7 & - & 6 \\
\hline No treatment (3 July 1970) & 一 & - & - & 9 & 19 & 0.03 & 11 \\
\hline Sixth day of 10 m-equiv $\mathrm{Na}$ diet & 124 & - & - & 10 & 8 & 0.05 & 11 \\
\hline $\begin{array}{l}\text { Third day of d-aldosterone } 0.5 \mathrm{mg} 8 \text { hourly } \\
\text { and } 9 \text { th day of } 10 \mathrm{~m} \text {-equiv } \mathrm{Na} \text { diet }\end{array}$ & - & - & - & 183 & 6 & $0 \cdot 18$ & 11 \\
\hline Third day of spironolactone $300 \mathrm{mg} /$ day & 12 & - & - & 22 & 7 & $0 \cdot 17$ & - \\
\hline Fourteenth day of spironalactone $300 \mathrm{mg} /$ day & 4320 & - & - & 57 & 106 & $0 \cdot 51$ & 一 \\
\hline Third day of aminoglutethimide $1 \mathrm{~g} /$ day & 66 & - & - & - & - & - & - \\
\hline Ten days after $\mathbf{R}$ adrenalectomy & 1650 & - & - & 5 & 1 & $0 \cdot 12$ & 12 \\
\hline Six months after $\mathbf{R}$ adrenalectomy & 274 & 一 & 1160 & 8 & 6 & 0.40 & 9 \\
\hline
\end{tabular}

Table Plasma renin and corticosteroid determinations

${ }^{1}$ See discussion 

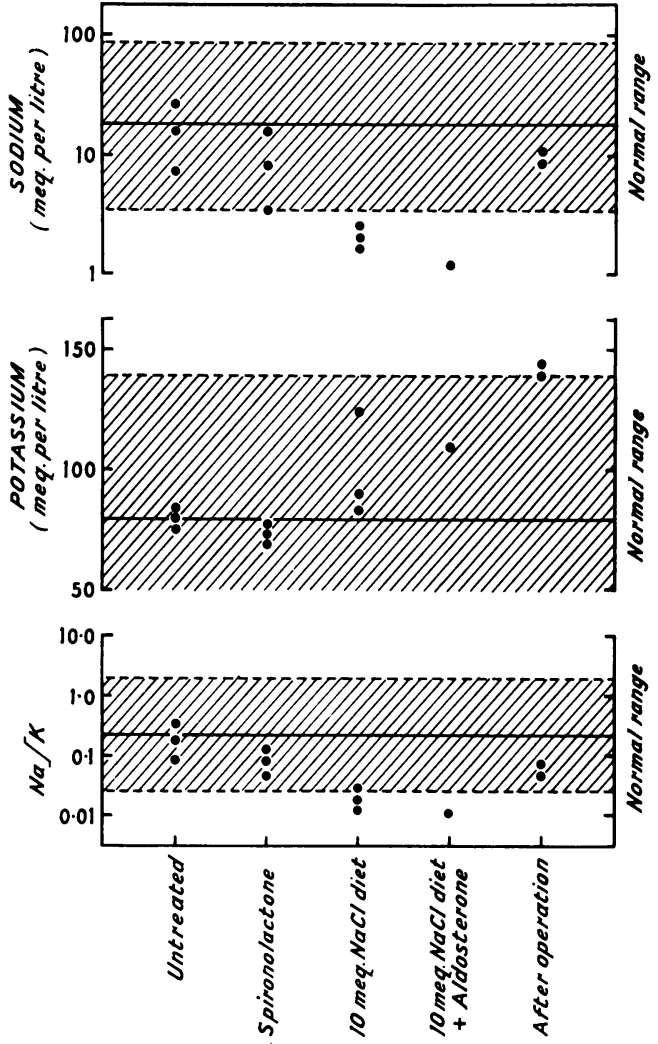

Fig 2 Concentrations of sodium and potassium and the sodium/potassium $(\mathrm{Na} / \mathrm{K})$ ratio in faecal dialysates.

restriction and increased to well above the upper limit of normal $(-60 \mathrm{mV})$ during treatment with aldosterone.

\section{HISTOLOGY OF ADRENAL ADENOMA}

The adrenal adenoma was largely comprised of clear cells with a few compact and zona glomerulosatype cells. No microadenomata were found in the excised adrenal. The zona glomerulosa was hypertrophied. The juxtaglomerular bodies appeared normal in a renal biopsy taken at operation. Moderate hyalinization was seen in renal and adrenal arteries.

\section{Discussion}

The hypokalaemia in this patient with periodic paralysis was clearly caused by the adrenal adenoma which was excised in July 1970. Investigation of renal function did not reveal any renal disease. Intrinsic potassium-losing renal disease is excluded

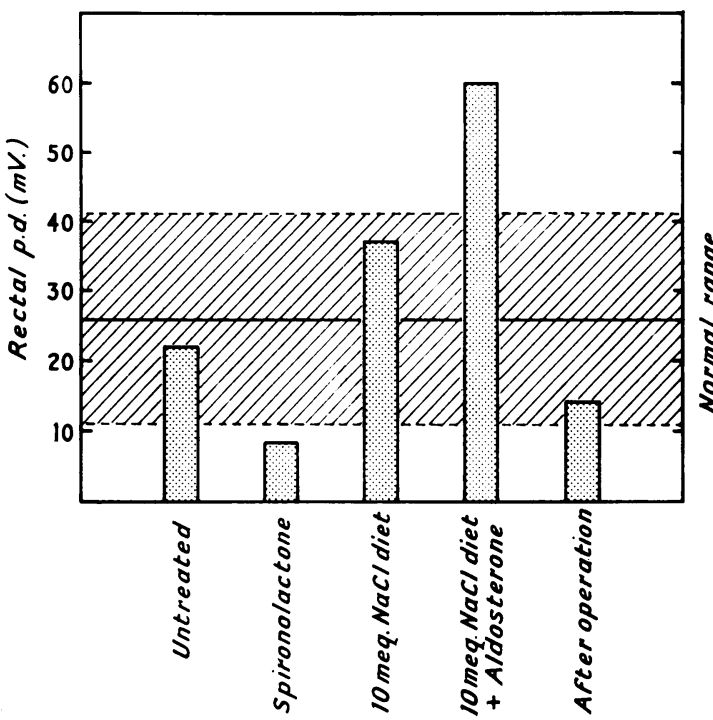

Fig 3 Rectal pd measured during the periods when faecal dialysates were obtained.

by the fact that neither hypokalaemia nor paralysis has recurred in the two years since operation. Her kidneys did not, however, conserve potassium normally before operation, because on the fourth day of a 20 m-equiv potassium diet she still had a negative balance of 10 to $20 \mathrm{~m}$-equiv including stool losses. The adenoma secreted a sodium-retaining hormone which profoundly suppressed plasma renin activity. The hormone was probably an adrenal steroid, because its sodium-retaining activity was blocked by spironolactone, an effect seen both in electrolyte balance studies and in release of renin suppression (table). Changes in potassium balance in short-term spironolactone studies were less impressive than the change in sodium, particularly on stopping spironolactone when, in spite of avid sodium retention, potassium loss was very small. A different time course in the effect of spironolactone upon sodium and potassium excretion is not, however, surprising in view of evidence of the partial independence of sodium reabsorption and potassium excretion in response to mineralocorticoids in both kidney and colon. Treatment with spironolactone for several weeks reversed and then prevented hypokalaemia. A prompt and impressive response to aminoglutethimide, an inhibitor of adrenal steroid biosynthesis, suggested that an adrenal hormone was responsible for the syndrome.

What adrenal hormone caused the syndrome? Even with carefully defined conditions of posture, diet, and treatment, it is difficult to define completely 
the relationship between the normal range for plasma aldosterone concentration in healthy, normotensive individuals and concentrations found in hypertensive patients. Our studies of 19 healthy medical students recumbent for longer than one hour showed resting levels of 0 to $5 \mathrm{ng}$ per $100 \mathrm{ml}$ (mean 2.5) (James, 1972). Under similar conditions Horton (1969) found a range of 2 to $8.5 \mathrm{ng}$ per 100 $\mathrm{ml}$ (mean 5.2) in 20 individuals. After recumbency overnight others report normal levels of 0.45 to 3.96 ng per $100 \mathrm{ml}$ (Balikian, Brodie, Dale, Melby, and Tait, 1968) and a mean of $6.5 \mathrm{ng}$ per $100 \mathrm{ml} \pm 3.9$ (SD) (Oddie, Coughlan, and Scoggins, 1972). Using the same method as ourselves, Brown, Ferriss, Fraser, Lever, Love, Robertson, and Wilson (1972) report 'normal values up to $18 \mathrm{ng}$ per $100 \mathrm{ml}$ (mean 8.0)'. With these uncertainties we cannot be sure whether or not aldosterone caused the syndrome. Attempts to suppress plasma aldosterone with saltloading or deoxycorticosterone might have helped to resolve the question (Biglieri, Slaton, Kronfield, and Deck, 1967), but at the time the normal colonic electrolytes and pd suggested other priorities in investigation. Deoxycorticosterone and corticosterone were normal. Although plasma potassium exceeded 3.3 m-equiv per litre whenever plasma corticosteroids were measured, it is possible that total body potassium was nevertheless reduced sufficiently to depress aldosterone secretion. Our measurements of total exchangeable potassium do not resolve this point. After three weeks without treatment in June when the plasma potassium was 2.7 m-equiv per litre the total exchangeable potassium at $24 \mathrm{hr}$ was 32.3 m-equiv per $\mathrm{kg}$ (expected value $35.6 \pm 7.0 \mathrm{~m}$-equiv per $\mathrm{kg}$ ). Three weeks earlier, on stopping spironolactone, the plasma potassium was $4.5 \mathrm{~m}$-equiv per litre and the total exchangeable potassium at $24 \mathrm{hr}$ was $28.9 \mathrm{~m}$-equiv per $\mathrm{kg}$. During treatment with spironolactone plasma concentrations of aldosterone, deoxycorticosterone, and corticosterone increased five to 10 -fold and we were unable to interpret the rise as evidence either for or against an aldosterone-secreting adenoma: certainly lack of autonomy does not exclude an aldosteronesecreting adenoma nor does failure of the excision of an adenoma to cure hypertension indicate that it was not responsible for excess mineralocorticoid (Brown, Davies, Ferriss, Fraser, Haywood, Lever, and Robertson, 1972). The concentrations of both aldosterone and deoxycorticosterone were lower after operation than before.

It was the lack of any evidence of excess mineralocorticoid upon the colon which made us particularly question the nature of the adrenal hormone. Measurements of sodium and potassium concentrations in colonic fluid and of rectal pd were normal.
Furthermore it could not be said that the colonic mucosa was refractory to mineralocorticoids: a response was obtained both to a low-salt diet and to exogenous aldosterone in a dose which gave a plasma aldosterone concentration similar to the highest we have seen with an adrenal adenoma (Richards, 1969). The question arises whether unrecognized cellular potassium depletion had modified the colonic response. For example, we have recently studied a man with a high plasma aldosterone whose faecal fluid electrolytes and rectal pd were normal. Although his plasma potassium was then normal his colon was, however, abnormal in that neither faecal electrolyte concentrations nor rectal pd altered in response to fludrocortisone, a finding which suggested that his colon was already maximally stimulated by aldosterone. Intracellular potassium depletion had probably reduced the extent to which aldosterone could stimulate sodium transport across his colonic mucosa, because, after a further period of potassium repletion, both faecal electrolyte concentrations and rectal pd were found to be in the hyperaldosterone range. The paradoxically normal findings in our present patient probably cannot be explained in the same way: her colon was not fully stimulated for a response was seen to the mild stimulus of salt depletion as well as to exogenous aldosterone. This response seems to deny the possibility that she was either profoundly potassium deficient, or that she had escaped from either the physiological or pharmacological actions of mineralocorticoids.

We were unable to measure 18-hydroxy-deoxycorticosterone which may possibly cause a similar syndrome (Melby, Dale, and Wilson, 1971), and we do not know whether 18-deoxycorticosterone affects the colon. The possibility remains that the adenoma secreted a hormone which affected the kidney but spared the colon. It is in any case important to realize that although excess mineralocorticoid is usually detectable in the colon it may be masked in patients with severe potassium depletion and, probably for a different and unknown reason, in patients such as the woman described here.

We thank Professor V. H. T. James and Dr M. Arnold for the plasma corticosteroid assays; $\mathrm{Dr}$ G. W. Boyd for renin estimations; Dr C. J. Edmonds for some of the measurements of rectal pd; Dr M. S. Campbell and Dr F. Lees for referring the patient to us. Ciba Ltd kindly supplied aminoglutethimide (Elipten).

\section{References}

Arnold, M. L., and James, V. H. T. (1971). Determination of deoxycorticosterone in plasma: double isotope and immunoassay methods. Steroids, 18, 789-801. 
August, J. T., Nelson, D. H., and Thorn, G. W. (1958). Response of normal subjects to large amounts of aldosterone. J. clin. Invest., 37, 1549-1555.

Balikian, H. M., Brodie, A. H., Dale, S. L., Melby, J. C., and Tait, J. F. (1968). Effect of posture on the metabolic clearance rate, plasma concentration and blood production rate of aldosterone in man. J. clin. Endocr., 28, 1630-1640.

Biglieri, E. G., Slaton, P. E., Jr., Kronfield, S. J., and Deck, J. B. (1967). Primary aldosteronism with unusual secretory pattern. J. clin. Endocr., 27, 715-721.

Boyd, G. W., Adamson, A. R., Fitz, A. E., and Peart, W. S. (1969). Radioimmunoassay determination of plasma-renin activity. Lancet, 1, 213-218.

Brown, J. J., Davies, D. L., Lever, A. F., Peart, W. S., and Robertson, J. I. S. (1965). Plasma concentration of renin in a patient with Conn's syndrome with fibrinoid lesions of the renal arterioles. J. Endocr., 33, 279-293.

Brown, J. J., Davies, D. L., Ferriss, J. B., Fraser, R., Haywood, E., Lever, A. F., and Robertson, J. I. S. (1972). Comparison of surgery and prolonged spironolactone therapy in patients with hypertension, aldosterone excess and low plasma renin. Brit. med. J., 2, 729-734.

Brown, J. J., Ferriss, J. B., Fraser, R., Lever, A. F., Love, D. R., Robertson, J. I. S., and Wilson, A. (1972). Apparently isolated excess deoxycorticosterone in hypertension. Lancet, 2, 243-247.

Charron, R. C., Leme, C. E., Wilson, D. R., Ing, T. S., and Wrong, O. M. (1969). The effects of adrenal steroids on stool composition, as revealed by in vivo dialysis of faeces. Clin. Sci., $37,151-167$.

Edmonds, C. J., and Godfrey, R. C. (1970). Measurement of electrical potentials of the human rectum and pelvic colon in normal and aldosterone-treated patients. Gut, 11, 330-337.

Edmonds, C. J., and Richards, P. (1970). Measurement of rectal electrical potential difference as an instant screening-test for hyperaldosteronism. Lancet, 2, 624-627.

Fraser, R., and James, V. H. T. (1968). Double isotope assay of aldosterone, corticosterone and cortisol in human peripheral plasma. J. Endocr., 40, 59-72.

Horton, R. (1969). Stimulation and suppression of aldosterone in plasma of normal man and in primary aldosteronism. J. clin. Invest., 48, 1230-1236.

James, V. H. T. (1972). Personal communication.

Melby, J. C., Dale, S. L., and Wilson, T. E. (1971). 18-hydroxydeoxycorticosterone in human hypertension. Circulat. Res., 28, Suppl. 2, 143-152.

Oddie, C. J., Coghlan, J. P., and Scoggins, B. A. (1972). Plasma deoxycorticosterone levels in man with simultaneous measurement of aldosterone, corticosterone, cortisol and 11-deoxycortisol. J. clin. Endocr., 34, 1039-1054.

Richards, P. (1969). Clinical investigation of the effects of adrenal cortiscosteroid excess on the colon. Lancet, 1, 437-442.

Richards, P. (1971). Detection of mineralocorticoid excess using spironolactone. In The Medical Uses of Spironolactone, edited by G. M. Wilson, pp, 17-26. Excerpta Medica, Amsterdam.

Shields, R., Miles, J. B., and Gilbertson, C. (1968). Absorption and secretion of water and electrolytes by the intact colon in a patient with primary aldosteronism. Brit. med. J., 1, 93-96.

Wrong, O. M., and Metcalfe-Gibson, A. (1965). The electrolyte content of faeces. Proc. roy. Soc. Med., 58, 1007-1009.

Wrong, O. M., Morrison, R. B. I., and Hurst, P. E. (1961). A method of obtaining faecal fluid by in-vivo dialysis. Lancet, 1, 12081209. 